\title{
Aldolases A and C Are Ribonucleolytic Components of a Neuronal Complex That Regulates the Stability of the Light- Neurofilament mRNA
}

\author{
Rafaela Cañete-Soler, ${ }^{1}$ Konda S. Reddy, ${ }^{1}$ Dean R. Tolan, ${ }^{2}$ and Jinbin Zhai ${ }^{1}$ \\ ${ }^{1}$ Division of Neuropathology, Department of Pathology and Laboratory Medicine, University of Pennsylvania School of Medicine, Philadelphia, \\ Pennsylvania 19103, and 2Department of Biology, Boston University, Boston, Massachusetts 02215
}

\begin{abstract}
A 68 nucleotide segment of the light neurofilament (NF-L) mRNA, spanning the translation termination signal, participates in regulating the stability of the transcript in vivo. Aldolases A and C, but not $\mathrm{B}$, interact specifically with this segment of the transcript in vitro. Aldolases $\mathrm{A}$ and $\mathrm{C}$ are glycolytic enzymes expressed in neural cells, and their mRNA binding activity represents a novel function of these isozymes. This unsuspected new activity was first uncovered by Northwestern blotting of a brainstem/spinal cord cDNA library. It was confirmed by two-dimensional fractionation of mouse brain cytosol followed by Northwestern hybridization and protein sequencing. Both neuronal aldolases interact specifically with the NF-L but not the heavy neurofilament mRNA, and their binding to the transcript excludes the poly(A)-binding protein (PABP) from the complex. Constitutive ectopic expression of aldolases $\mathrm{A}$ and $\mathrm{C}$ accelerates the decay of a neurofilament transgene (NF-L) driven by a tetracycline inducible system. In contrast, mutant transgenes lacking mRNA sequence for aldolase binding are stabilized. Our findings strongly suggest that aldolases $\mathrm{A}$ and $\mathrm{C}$ are regulatory components of a light neurofilament mRNA complex that modulates the stability of NF-L mRNA. This modulation likely involves endonucleolytic cleavage and a competing interaction with the PABP. Interactions of aldolases A and C in NF-L expression may be linked to regulatory pathways that maintain the highly asymmetrical form and function of large neurons.
\end{abstract}

Key words: neuronal aldolases; neurofilaments; RNA binding; posttranscriptional regulation; endonucleolytic cleavage; distributive exonuclease; poly(A)-binding protein; PABP

\section{Introduction}

Diversity in protein evolution is generally believed to arise from mutations in reduplicated genes (Brosius, 2003). Occasionally, bifunctional activities are discovered in a single gene product. Such instances may represent the convergence of separate genetic components. Alternatively, they may reflect the derivation of multiple functions as a result of changes in subcellular localization, conformational state, concentration of interactive molecules, or cell specificity (Wilkinson and Shyu, 2001; Jeffery, 2003). The latter possibility is exemplified by enzymes in the glycolytic pathway. Whereas glycolytic enzymes have evolved as a highly conserved, universal set of enzymes for converting monosaccharides into energy, they also reveal some vestiges of an ancient past. It has been known that enzymes display RNAbinding properties, suggesting a possible linkage to a primordial

Received Feb. 1, 2005; revised March 16, 2005; accepted March 22, 2005.

This work is dedicated to the memory of Doña Antonia Soler and her surviving husband Don José Cañete (Córdoba, Spain). We are indebted to Dr. Virginia M. Lee for sharing the human NF-L plasmid, Drs. D. Schoenberg and G. Dreyfuss for the generous gift of polyclonal and monoclonal PABP, and Dr. Hawkes for anti-zebrin antibodies. We apologize to the contributors in the field whose relevant work could not be cited because of space limitations.

Correspondence should be addressed to Rafaela Cañete-Soler, Division of Neuropathology, Department of $\mathrm{Pa}$ thology and Laboratory Medicine, University of Pennsylvania School of Medicine, 608A Stellar Chance, Philadelphia, PA 19103. E-mail: racansol@mail.med.upenn.edu.

DOI:10.1523/JNEUROSCI.0885-05.2005

Copyright $\odot 2005$ Society for Neuroscience $\quad$ 0270-6474/05/254353-12\$15.00/0
RNA-binding world (Hentze, 1994). In some instances, these RNA-binding properties may have evolved as moonlight activities, such as the one exemplified by the role of aconitase in regulating iron metabolism in the cell (Kennedy et al., 1992; Hentze and Kuhn, 1996) or the RNA binding activities of the nicotinamide adenine dinucleotide-dependent dehydrogenases (Sioud and Jespersen, 1996; Nagy et al., 2000; Pioli et al., 2002). The nuclear form of glyceraldehyde-3-phosphate dehydrogenase binds directly to Octl and is part of a complex that links the histone $\mathrm{H} 2 \mathrm{~B}$ transcriptional machinery to the cell cycle and metabolic cell status (Zheng et al., 2003).

The markedly asymmetrical neuronal shape is established and maintained by the synthesis, assembly, and translocation of cytoskeletal proteins from the neuronal perikarya into neuritic processes. The extraordinary size of large axons in subsets of neurons with dimensions $>20,000$-fold greater than the size of the perikarya is maintained by vast numbers of neurofilaments (NFs) that fill the axon and undergo a steady slow proximodistal axonal translocation. NFs are heteropolymers in vivo and require the presence of the light subunit (NF-L) for assembly (Ching and Liem, 1993; Lee et al., 1993), thereby conferring a dominant role to the regulation of NF-L subunit expression. Deletion of NF-L does not lead to an obvious phenotype (Zhu et al., 1998), but overexpression of a wild-type (wt) NF-L transgene (Xu et al., 1993) or low-level expression of a mutant NF-L transgene (Lee et 
al., 1994) causes motor neuron degeneration. Severe motor neuron degeneration is elicited by a mutation in a destabilizing element in the $3^{\prime}$-untranslated region (UTR) of the NF-L mRNA (Cañete-Soler et al., 1999) and can be reproduced by expression of mutant or wild-type NF-L destabilizing element in the $3^{\prime}$-UTR of a green fluorescent protein (GFP) reporter transgene (Nie et al., 2002). The findings suggest that the control of NF-L mRNA stability is a key upstream event in regulating NF metabolism and is an essential component of pathways maintaining neuronal homeostasis. Here, we identify aldolases $\mathrm{A}$ and $\mathrm{C}$ as major NF-L mRNA binding proteins that regulate the stability of the transcript by competing with poly(A)-binding protein (PABP). To our knowledge, this is the first time that a neuronal metabolic enzyme is shown to regulate the stability of a prominent neuronspecific transcript, which opens novel perspectives for understanding mechanisms of neuronal function and dysfunction.

\section{Materials and Methods}

All of the reagents used in this study were molecular biology grade from Sigma (St. Louis, MO), Amersham Biosciences (Piscataway, NJ), Clontech (Palo Alto, CA), and Promega (Madison, WI). Radionucleotides were obtained from Amersham Biosciences. Hemagglutinin (HA) monoclonal and polyclonal anti-aldolase antibodies were obtained from Santa Cruz Biotechnology (Santa Cruz, CA). CD1 mice (Charles River Laboratories, Wilmington, MA) were used following the guidelines established by the University of Pennsylvania Animal Regulatory Affairs. Cell lines were purchased from American Type Culture Collection (Manassas, VA) and cultured following American Type Culture Collection protocols. Brain and liver as well as cell line extracts were prepared as described previously (Cañete-Soler et al., 1998b).

Northwestern screening of a brainstem/spinal cord cDNA library. The Northwestern screening of the brainstem/spinal cord cDNA library was performed as described previously (Cañete-Soler et al., 2001).

Two-dimensional PAGE and matrix-assisted laser desorption mass spectroscopy. The two-dimensional (2D) fractionation of $50 \mu \mathrm{g}$ of mouse brain proteins was performed by isoelectric focusing using an IPGphor isoelectric focusing system and precast immobiline IPG strips (Amersham Biosciences) and the second dimension SDS-PAGE using a Hoefer SE600 vertical system (Hoefer Scientific, San Francisco, CA). All of the procedures followed the instructions of the manufacturer. Proteins were transferred to polyvinylidene difluoride membranes, and replicate samples were hybridized to internally labeled NF-L 68 RNA or nonspecific SK +70 RNA or end-labeled homoribopolymer (poly C) to selectively identify bona fide interactions. Proteins aligned with specific neurofilament RNA hybridization spots were excised and submitted to the protein facility at the Wistar Institute for matrix-assisted laser desorption mass spectroscopy (MALDI-MS) and Edman sequencing (Speicher and Reim, 1977; Speicher et al., 2000)

Expression and purification of recombinant aldolases. Full-length sequences of aldolases A and C were obtained by PCR of a mouse spinal cord cDNA library using specific primers followed by in-frame subcloning into appropriate restriction sites of pGEX-6 vectors. All constructs were fully sequenced by the DNA Sequencing Facility at the University of Pennsylvania School of Medicine (Philadelphia, PA). Glutathione $S$-transferase (GST)/aldolase fusion proteins were expressed and purified following standard procedures, and the GST moiety was removed by PreScission protease (Amersham Biosciences) followed by three rounds of purification using glutathione Sepharose $4 \mathrm{~B}$ columns according to the protocols of the manufacturer. Purified aldolases were dialyzed against buffers for downstream applications and aliquoted and kept at $-70^{\circ} \mathrm{C}$.

Electrophoretic mobility shift, Northwestern assay, and Western blot assay. Electrophoretic mobility shift assays were performed as described previously (Chen et al., 1992) with minor modifications. Briefly, 10-75 $\mu \mathrm{g}$ of cytoplasmic extracts (brain or liver) or $0-0.250 \mu \mathrm{M}$ purified recombinant proteins was incubated with $1 \mathrm{ng}$ of gel-purified radiolabeled NF-L wt or NF-L mutant variants for $5 \mathrm{~min}$ at $37^{\circ} \mathrm{C}$, followed by incubation with RNase $\mathrm{T} 1$ for $10 \mathrm{~min}$ at $37^{\circ} \mathrm{C}$. Reactions were terminated by the addition of $5 \mathrm{mg} / \mathrm{ml}$ final concentration of heparin and loaded onto a native $5 \%$ polyacrylamide gel in $0.5 \times \mathrm{TBE}(90 \mathrm{~mm}$ Tris-borate and $2 \mathrm{~mm}$ EDTA, pH 8.3).

Northwestern analyses of brain or liver complexes were performed by excising brain proteins bound to unlabeled NF-L RNA from native gels. A parallel identical binding reaction with radiolabeled NF-L RNA was used as an orientation marker for excision of relevant complexes. Proteins were eluted from acrylamide slices by incubation in protein elution buffer at $37^{\circ} \mathrm{C}$ for several hours and concentrated as described previously (Holcik and Liebhaber, 1997). Eluted proteins were fractionated in 10\% SDS-PAGE, transferred to nitrocellulose, renatured, and hybridized with radiolabeled NF-L 68, SK plus 70 RNA, and poly(C). Hybridization and washing protocols were followed as described previously (Cañete-Soler et al., 2001).

RNA transcripts were synthesized by SP6 or T7 RNA polymerases (Promega) using appropriate templates in the presence of $\alpha^{\mathrm{P} 32}$-UTP or end-labeled with $\gamma^{\mathrm{P} 32}$-ATP. Transcripts were uncapped unless indicated otherwise. In that instance, the transcription reaction was performed, including $1 \mathrm{~mm}$ final concentration of synthetic cap structure (New England Biolabs, Beverly, MA). Radiolabeled and unlabeled transcripts used in competition assays were denatured at $90^{\circ} \mathrm{C}$ for $2 \mathrm{~min}$ and kept on ice for $1 \mathrm{~min}$ before addition to the binding reactions.

Western blot analyses were performed by fractionating 30-50 $\mu \mathrm{g}$ of cytoplasmic extracts or 5-50 ng of purified aldolases in 10\% SDS-PAGE and transferred to nitrocellulose. For immunodetection, we used commercially available monoclonal HA and polyclonal aldolase A antibody (Santa Cruz Biotechnology) as well as monoclonal anti-Zebrin II (gift from Dr. Hawkes, University of Calgary, Calgary, Alberta, Canada). The ECL system (Amersham Biosciences) was used following the instructions of the manufacturer.

Circular dichroism. RNAs for circular dichroism (CD) were obtained by SP6/T7 transcription from appropriate templates, purified, and used in phosphate buffer, $\mathrm{pH} 7.4$, at a final concentration of $1 \mu \mathrm{M}$. Purified aldolases, dyalized against phosphate buffer, were used at a final concentration of $10 \mu \mathrm{M}$. Spectra were recorded on an AVIV 62DS spectropolarimeter (Aviv Associates, Lakewood, NJ) using rectangular quartz cells with a path length of 1 or $0.2 \mathrm{~cm}$, respectively. Thermal control was maintained by a thermoelectric unit with a Nestlab (Newington, $\mathrm{NH}$ ) CFT-33 refrigerated, recirculating water bath and heat sink.

Cell transfection, immunoprecipitation, reverse transcription- $P C R$, and ribonuclease protection assays. Neuro-2a cells that express very low levels of NF-L and higher levels of the heavy neurofilament subunit (NF-H) were transfected with an HA-expressing vector or cotransfected with the neurofilament light subunit and respective $\mathrm{HA}$ aldolase $\mathrm{A}$ or aldolase $\mathrm{C}$ cDNAs. A luciferase reporter was included to correct for transfection efficiency. All transfections contained the same amount of DNA by adding vector DNA as needed. Cell lysates were harvested at $48 \mathrm{~h}$ after transfection and were HA-immunoprecipitated at a ratio of 9:1. Briefly, $900 \mu \mathrm{l}$ of lysate was precipitated at $4^{\circ} \mathrm{C}$ for $2-4 \mathrm{~h}$ using a monoclonal HAagarose conjugate antibody (Santa Cruz Biotechnology), and $100 \mu \mathrm{l}$ was stored at $4^{\circ} \mathrm{C}$ as total cell lysate (control). The extent of immunoprecipitation was determined by Western blot analysis. All antibody-treated samples were spun, and the immunoprecipitates were washed and resuspended in elution buffer. All fractions, including one-tenth of the total cell lysate, were DNase I treated for $10 \mathrm{~min}$ at $37^{\circ} \mathrm{C}$. RNA was obtained by phenol chloroform extraction and ethanol precipitation. RT was performed using the Superscript System (Invitrogen, San Diego, CA) and PCR amplification with specific primers from neurofilament transgene and vector sequences. To better assess the extent of product amplification, the PCRs were supplemented with $0.1 \mu \mathrm{M}$ end-labeled sense primer, and aliquots were taken after 12 and 22 cycles. The presence and integrity of mRNA, before and after immunoprecipitation, was assessed using specific primers for the endogenous neurofilament heavy subunit. To account for spurious amplification, we used specific primers for a 540 fragment of v-erb B (Clontech).

Nonneuronal COS cells were obtained from the American Type Culture Collection and transiently transfected using Lipofectamine (3.5 $\mu \mathrm{l} / \mu \mathrm{g}$ DNA; Invitrogen). Transfection mixtures contained the tetracycline transactivator (tTA) (pUHD15.1M) and NF-L wt, aldolase A, or 
A

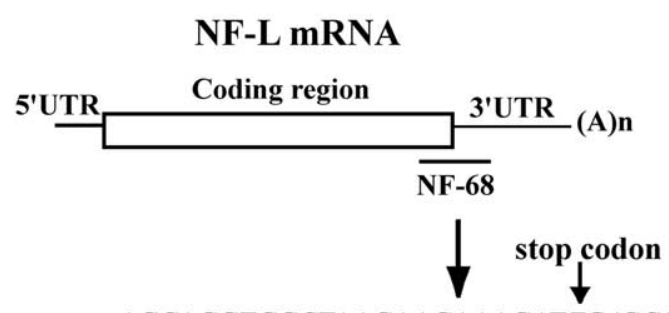

AGCAGGTGGCTAAGAAGAAAGATTGAGCCCTATT

CCCAACTATTCCAGGAAAAGTTCTCCCCAATCAG
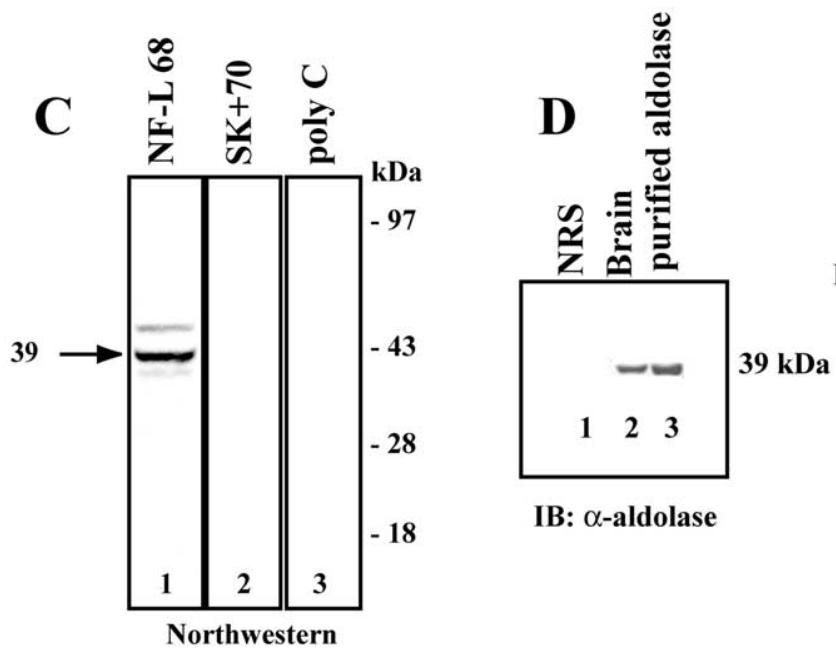

IB: $\alpha$-aldolase

Figure 1. Detection of specific interactions between a $68 \mathrm{nt}$ segment of neurofilament RNA and cytoplasmic extract from mouse tissues. $A$, Schematic diagram of NF-L mRNA showing location and sequence of destabilizing element. $B$, Electrophoretic mobility shift assay after incubation at $37^{\circ} \mathrm{C}$ of $1 \mathrm{ng}$ of radiolabeled NF-L 68 with $50 \mu \mathrm{g}$ of brain (lane 2) or liver (lane 3) extracts for 5 min before digestion with RNase T1. Binding reactions were analyzed on a native low-ionic strength $5 \%$ polyacrylamide gel. $C$, Identification of polypeptides in a brain extract RNA-protein complex by Northwestern analysis. A binding reaction identical to that shown in $\boldsymbol{B}$ (lane 2) was performed with unlabeled specific RNA probe and brain extract and resolved on a native $5 \%$ gel. The complex was excised from the gel, and the proteins were eluted and fractionated in a $10 \%$ SDS-PAGE. D, Western blot analysis of brain extract RNA-protein complex. Proteins from brain RNA-protein complex in $\boldsymbol{B}$ (lane 2) were immunoblotted (IB) using anti-aldolase antibody. A control normal rabbit serum (NRS) is shown in lane 1, protein from brain ribonucleoprotein complex is shown in lane 2 , and control purified aldolase is shown in lane 3.

aldolase $\mathrm{C}$ cDNAs in expression vectors driven by the tetracycline inducible promoter (tet OFF). A luciferase reporter gene (pHUD13.3) driven by the same promoter was included (ratio, $0.05: 1$ total DNA) to monitor transactivation in the absence of doxycycline and transcription arrest after the addition of $0.5 \mu \mathrm{g} / \mathrm{ml}$ ligand. The reporter was also used to correct for transfection efficiency. Each set of transfections contained the same amount of DNA by adding the expression vector alone, as needed. Transfection mixtures prepared in Optimem (Invitrogen) were added to multiple plates and incubated for $12-18 \mathrm{~h}$ in $1 \%$ serum, followed by a transcription pulse for $2 \mathrm{~h}$ in the presence of $10 \%$ serum. Then, doxycycline was added, and mRNA as well as total protein was harvested at varying times in the absence of tetracycline (time 0 ) or after readdition of the ligand. Luciferase activity was measured by luminometry, rates of mRNA degradation were measured by ribonuclease protection assay, and aldolase protein levels were measured by Western blot analysis using a polyclonal anti-PABP obtained from Dr. D. Schoenberg (Ohio State University, Columbus, OH) (1:500) and commercial polyclonal antialdolase A (1:150), anti-aldolase C (1:50), or monoclonal anti-zebrin (1:3000) obtained from Dr. Hawkes.

Ribonuclease protection assays were performed as described previously (Cañete-Soler et al., 1998a).

\section{Results}

Identification of neuronal aldolases A and $\mathrm{C}$ as neurofilament RNA-binding proteins

It was shown that a 68 nucleotide (nt) segment of the NF-L mRNA was essential for NF-L mRNA stabilization in neuronal cells (Cañete-Soler et al., 1998a) (Fig. 1A). Moreover, gel-shift assays revealed that one or more proteins present in neuronal tissue formed a stable complex with this RNA (Fig. $1 B$ ). The complex could be disrupted by adding an excess of poly $(\mathrm{C})$. To identify NF-L mRNA binding proteins, we first performed Northwestern blotting (Wilusz, 1997) of a brainstem/spinal cord cDNA library for the following reasons: (1) the brain complex that forms on the NF-L 68 was very stable and therefore amenable to stringent washing protocols; (2) the experimental evidence that the 68 nt RNA probe was stable for $\sim 1 \mathrm{~h}$ at $37^{\circ} \mathrm{C}$; (3) the brain RNA-protein complex was sensitive to $\operatorname{poly}(\mathrm{C})$, and the property could be used to selectively identify NFRNA binding factors that were not poly $(\mathrm{C})-\mathrm{RNA}$ binding proteins; and (4) the 68 nt RNA, used as a probe, could potentially identify NF-RNA transacting factors involved in regulating the stability of the transcript and/or involved in a motorneuron-like disease phenotype observed in transgenic mice. This library was selected because the brainstem and spinal cord express the highest levels of neurofilaments in the CNS. We first identified the neuronal exchange factor p190RhoGEF (Cañete-Soler et al., 2001). Three inserts of $\sim 1.2 \mathrm{~kb}$ were partially sequenced $(\sim 600 \mathrm{bp})$, and the sequences matched those of aldolase (data not shown). Because the finding was unexpected, the interaction was probed by binding radiolabeled NF-L 68 nt RNA to proteins in brain extracts and examining the electrophoretic mobility shift (EMSA) of complexes formed under native conditions. With brain extract, an electrophoretic mobility shift was observed, whereas no shift was detected with liver extracts under identical conditions (Fig. $1 B$ ). SDS-PAGE and actin immunoblots showed that the protein content and integrity of the two extracts were similar (data not shown). A parallel EMSA with brain extracts and unlabeled NF-L 68 RNA was used to excise the complex from the native gel. The protein components were refractionated by SDS-PAGE followed by Northwestern confirmation of specific NF-L RNA binding after renaturation (Fig. 1C). Nonspecific vector sequence SK+70 RNA or poly(C) did not bind. A major protein with an apparent molecular weight (MW) of $39 \mathrm{kDa}$ and two additional proteins of 36 and $58 \mathrm{kDa}$ bound to this probe and were part of the complex in brain extracts. The major $39 \mathrm{kDa}$ protein corresponded to aldolase as revealed by a parallel immunoblot with anti-aldolase antibody (Fig. 1D). These results support the cDNA screening data. 
A
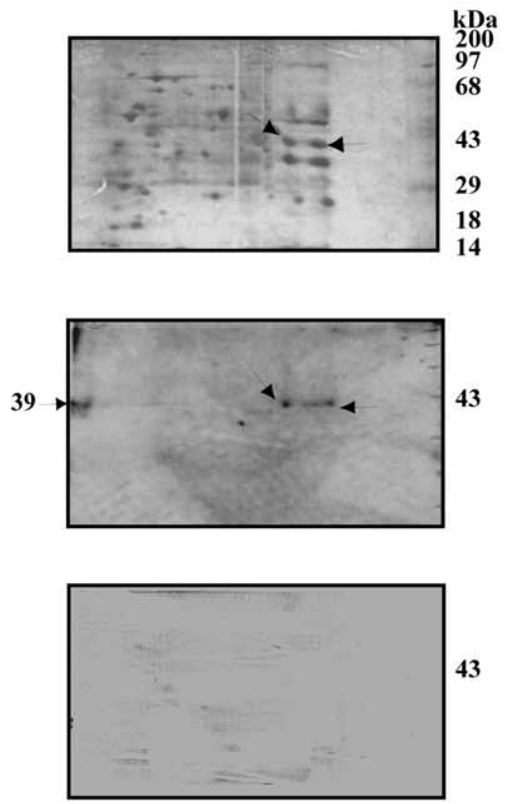

B
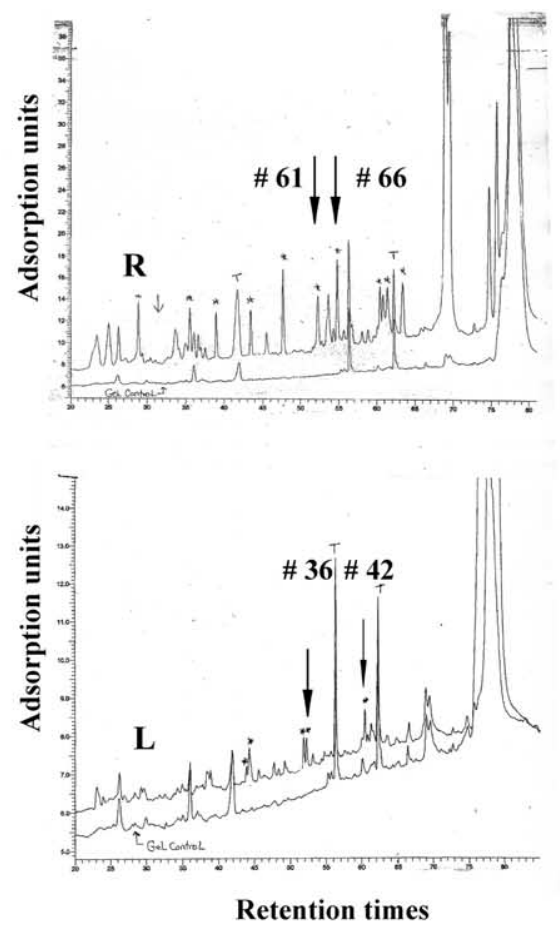

C

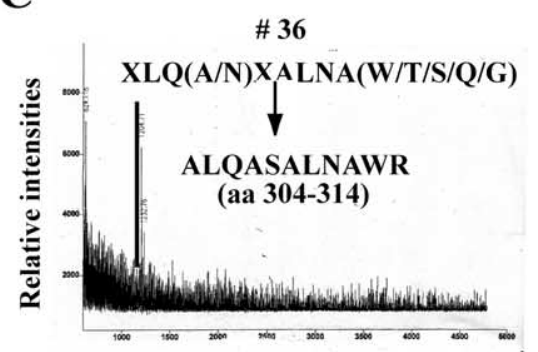

-

\# 42

(A/G/S)VVPLAGT(G/D)

(aa 111-133)

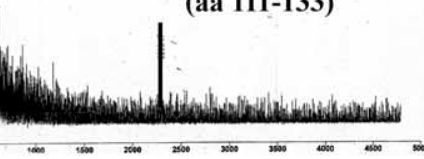

\# 66

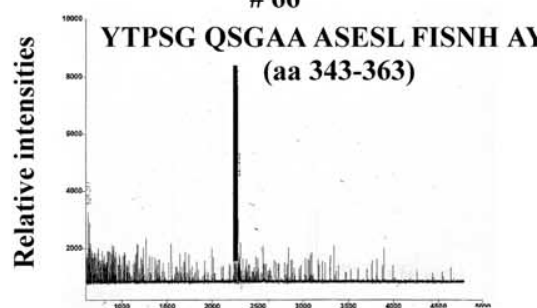

$\mathbf{m} / \mathbf{z}$

Figure 2. Identification of neuronal aldolases A and C as components of a brain extract neurofilament RNA-protein complex. A, 2D-PAGE and Northwestern analysis of proteins from $50 \mu \mathrm{g}$ of mouse brain cytoplasmic extract stained with silver (top) or transferred to nitrocellulose and hybridized separately with an NF-L $68 \mathrm{nt}$ RNA probe (middle) or a nonspecific SK + 70 (bottom) identified two $39 \mathrm{kDa}$ RNA-binding proteins (arrowhead within the gel). The left lane in the middle panel shows hybridization with two $39 \mathrm{kDa}$ proteins in mouse brain proteins separated by $1 D$ electrophoresis. The polypeptides present in the two spots were digested within gel slices with trypsin and extracted. $\boldsymbol{B}$, HPLC chromatograms of gel-eluted peptides in $\boldsymbol{A}$ from the right spot (R) or the left spot (L). C, MALDI of HPLC fractions selected for Edman sequencing. Sequences (listed above) matched those of aldolase C (fractions 36 and 42 ) and aldolase A (fraction 66). $\mathrm{m} / \mathrm{z}$, Mass-to-charge ratio.

To confirm that the $39 \mathrm{kDa}$ protein was a major component of the RNA-protein complex, mouse brain cytoplasmic extracts were separated by 2D-gel electrophoresis (Fig. 2 A), transferred to nitrocellulose, and hybridized separately to radiolabeled NF-L 68 or vector SK+70. Two major spots of $39 \mathrm{kDa}$ that specifically hybridized to the NF-L 68 RNA confirmed the EMSA studies. No specific binding was detected in filters hybridized with the $\mathrm{SK}+70 \mathrm{nt}$ RNA probe.

The identity of the $39 \mathrm{kDa}$ proteins bound to NF-RNA was determined by Edman sequencing. The proteins were digested within gel slices with trypsin, and the peptides were extracted and separated by HPLC (Fig. 2B). Peptides corresponding to fractions 61 and 66 from the right spot (Fig. $2 B, \mathrm{R}$ ) and fractions 36 and 42 from the left spot (Fig. $2 B, \mathrm{~L}$ ) were selected for Edman sequencing. The sequence from fraction 36 was unclear (XLQ (A/N) XALNA (W/T/S/Q/G) but corresponded to a tryptic peptide (ALQASALNAWR) from amino acids 304-314 (Fig. 2C). The presence of $\mathrm{N}$ at position 8 (amino acid 311) in the sequence from fraction 36 distinguishes this as aldolase C (Pezza et al., 2003). The MW of this peptide determined by MALDI-MS was 1204.7 Da, which was close to the predicted mass of $1200.4 \mathrm{Da}$ for this aldolase $C$ peptide. Similarly, the sequence from fraction 42 was $(A / G / S)$ VVPLAGT (G/D), which would correspond to the beginning of a tryptic peptide from amino acids 111-133, and the $\mathrm{G}$ or $\mathrm{D}$ at position 9 distinguishes this as aldolase $\mathrm{C}$. Aldolase $\mathrm{A}$ has an $\mathrm{N}$ at this position (amino acid 119). One of the fragments from the right spot (fraction 66) corresponded to the most isozyme-specific tryptic fragment at the C terminus (Rottmann et al., 1987) (YTPSGQSGAAASESLFISNHAY), which was clearly derived from aldolase A. The MALDI (Fig. 2C) confirmed that this was aldolase A with an observed mass of $2258.8 \mathrm{Da}$, which was approximately the same as the calculated mass of $2258.0 \mathrm{Da}$ and $58 \mu \mathrm{m}$ greater than that corresponding to aldolase $\mathrm{C}$. The sequence from fraction 61 (GVVPLAGTNGWTTTQGLDG) was from the corresponding aldolase A peptide as that in fraction 42, but the sequence was much clearer. The location of identified sequences for aldolase A and C is shown in the supplemental material (available at www.jneurosci.org). These data confirmed that the brain extract $39 \mathrm{kDa}$ proteins identified by onedimensional (1D) Northwestern blotting (Fig. 1) were the neuronal glycolytic enzymes aldolase $\mathrm{A}$ and aldolase $\mathrm{C}$.

\section{The formation of a neurofilament RNA complex by brain} extract is dependent on the presence of aldolase, restricted to the neuronal isozymes, and enhanced when the transcript is capped

It is possible that aldolase, a major protein, is masking the actual binding protein in Northwestern analyses. To confirm the binding of aldolase to the NF-L 68 element, we performed EMSA using recombinant purified aldolase and brain extract as positive 
A

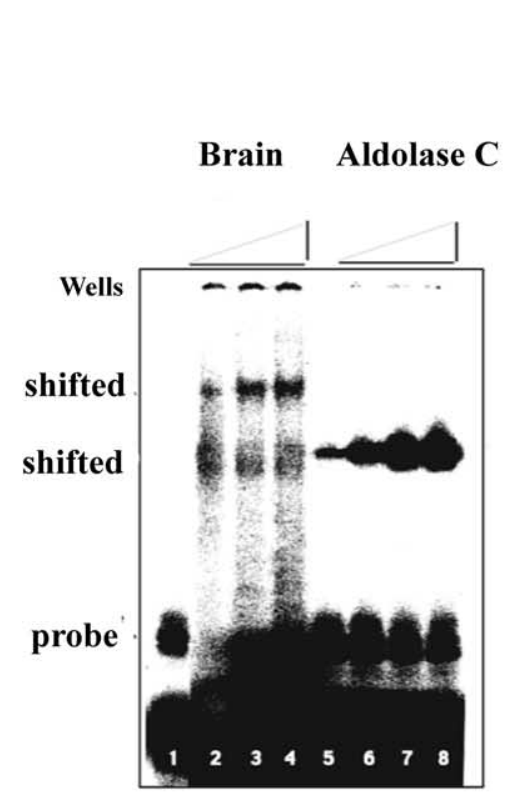

B

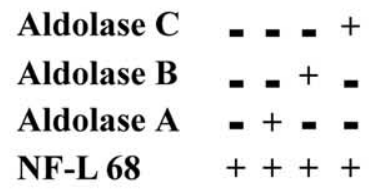

C

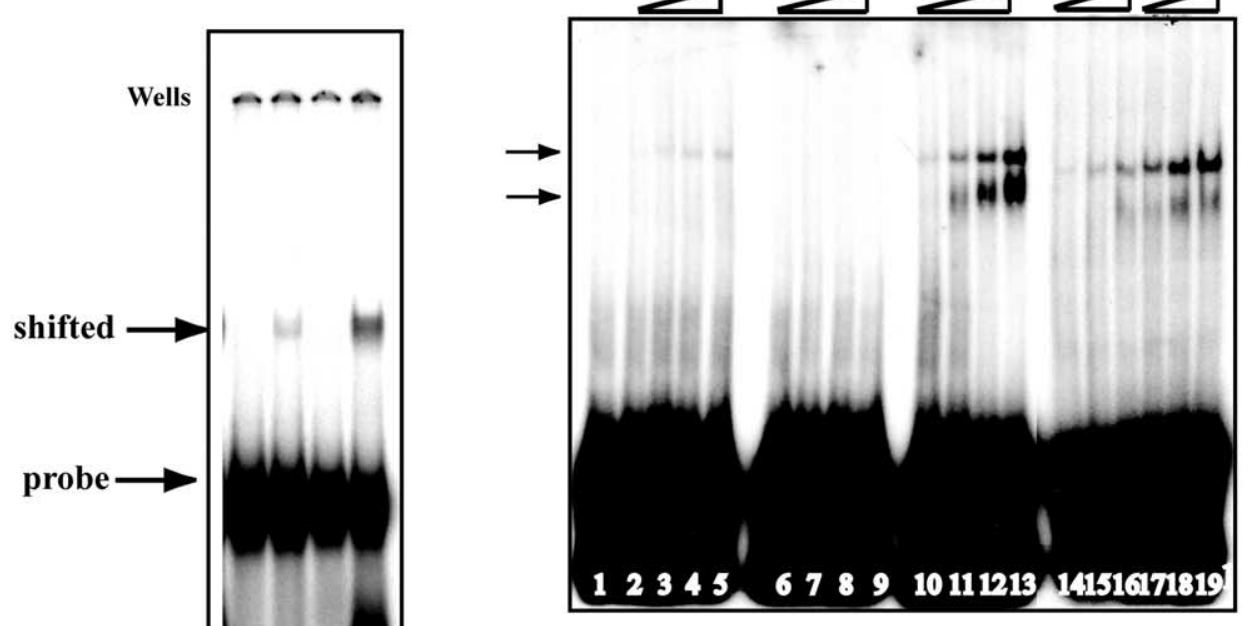

Figure 3. Isozyme-dependent formation of neurofilament RNA-protein complexes. Binding reactions were performed as described in Figure 1. $\boldsymbol{A}$, Electrophoretic mobility shift assay of internally radiolabeled NF-68 RNA with $0-80 \mu \mathrm{g}$ of brain extract (lanes 1-4) or with $60-200 \mathrm{~nm}$ purified aldolase $\boldsymbol{C}$ (lanes $5-8$ ). $\boldsymbol{B}$, Formation of isozyme-dependent complexes after incubation of radiolabeled NF-L68 RNA with 10 nm purified aldolase A (lane 2 ), aldolase B (lane 3), or aldolase C (lane 4). C, Isozyme dose-response and magnesium requirements for complex formation. A total of 10-80 nm purified aldolase A (lanes 2-5), aldolase B (lanes 6-9), and aldolase C (lanes 10-13) was incubated with capped internally labeled NF-68 RNA, and complexes were resolved in a nondenaturing $5 \%$ acrylamide gel. Parallel binding reactions in the presence of 30 mm EDTA were conducted with 20 - 80 nm aldolase A (lanes 14-16) or aldolase C (lanes 17-19).

control. As shown in Figure $3 A$, incubation of $0-80 \mu \mathrm{g}$ of brain extract with radiolabeled NF-L 68 produced slow- as well as fastmigrating complexes (Fig. 3A, lanes 2-4), consistent with the existence of at least two proteins as revealed by Northwestern hybridization (Fig. 1C, lane 1). Purified aldolase C (20-100 nm) retarded the migration of the riboprobe in a dose-dependent manner (Fig. 3A, lanes 5-8). A single complex in this case suggests that aldolase $\mathrm{C}$ has only one binding site in the uncapped transcript. Similar results were obtained with aldolase A (data not shown).

To determine whether the RNA-binding activity was isozyme dependent, all three aldolases (A, B, and C) were expressed in GST vectors, and the GST moiety was removed by PreScission protease. The GST-free aldolases were repurified using glutathione Sepharose $4 \mathrm{~B}$ columns and dialyzed. Only aldolases A and C (Fig. $3 B$ ) were able to retard the migration of the transcript (compare lanes 2 and 4 with lane 3 ). This observation was not the result of differences in protein quality, because the three aldolase preparations had the expected specific activities (Penhoet and Rutter, 1971 ) and were $>95 \%$ pure as judged by SDS-PAGE (data not shown).

The affinity of aldolases for the neurofilament transcript was estimated by incubating increasing concentrations of respective purified aldolases $(0-240 \mathrm{nM})$ with uncapped (Fig. $3 B$ ) or capped radiolabeled NF-68 RNA (Fig. $3 C$ ). The $K_{\mathrm{D}}$ of each aldolase was estimated from the plot of bound/free RNA versus aldolase concentration and was $30 \pm 8$ and $12 \pm 8 \mathrm{~nm}$ for aldolase $\mathrm{A}$ and aldolase $\mathrm{C}$, respectively. Binding of either neuronal aldolase to the transcript was dose dependent and saturable, reaching a plateau at $120-150 \mathrm{~nm}$ (data not shown).

The requirement for magnesium in the binding of aldolases to the transcript was investigated by performing the binding reactions with $30 \mathrm{~mm}$ EDTA or $5 \mathrm{~mm}$ magnesium. A capped radiolabeled NF-68 was allowed to bind aldolases at $37^{\circ} \mathrm{C}$. In this instance, aldolase A formed one complex (Fig. 3C, lanes 2-5), whereas aldolase $\mathrm{C}$ formed two complexes (Fig. 3C, lanes 10-13). Aldolase A appeared to be magnesium independent, because the formation of the complex was not disrupted by the presence of EDTA (Fig. 3C, compare lanes 2-5 with lanes 14-16). In contrast, aldolase $\mathrm{C}$ binding reflected a dual behavior, because one of the complexes was disrupted with EDTA (Fig. 3C, bottom band; compare lanes 11-13 with lanes 17-19); however, the formation of the second complex was magnesium independent (Fig. 3C, top band; compare lanes 11-13 with lanes 17-19). Together, the findings show that the formation of a neurofilament RNA complex in brain extract is dependent on the presence of aldolase, is restricted to the two neuronal isozymes, and has high affinity. In addition, we show that the binding of aldolase $\mathrm{C}$ is enhanced when the transcript is provided with a cap structure and suggests that aldolase $\mathrm{C}$ could have different binding domains with differential preference for magnesium (Ross, 1999).

Specificity of aldolase binding to neurofilament transcripts To assess the ability of aldolase to bind NF-L mRNA specifically and not RNA in general, other RNAs were used to compete with radiolabeled NF-L 68 for interaction with aldolase C (Fig. 4A). To this end, radiolabeled NF-L 68 was incubated with aldolase $\mathrm{C}$ in the absence (Fig. $4 A$, lane 2 ) or presence of 10 - to 100 -fold excess of unlabeled transcript (lanes 3-7). A 10-fold excess of unlabeled NF-L 68 (Fig. 4A, lane 3) reduced binding significantly, and a 40 -fold excess completely abolished the interaction (lane 4). In contrast, 0 - to 800 -fold of unrelated simian virus 40 RNAs (Fig. 
$4 A$, lanes $8-13$ ) or 10 - to 100 -fold of two different adenosine- uracil (AU)-rich elements (lanes 14-19), a 35 nt AU-rich element of tumor necrosis factor $\alpha$ (TNF $\alpha)$ (Ford et al., 1999), and the AU-rich element of interleukin-3 (IL-3)/3'-UTR were unable to affect binding of aldolase to the NF-RNA, although a modest effect was observed with a 100 -fold excess of TNF $\alpha$ and IL-3 adenosine-rich element (ARE). This indicated that aldolase binding to NF-L RNA is dependent on a specific sequence in the 68 nt RNA.

Direct and specific interaction of aldolase with the NF-L mRNA in solution was investigated by circular dichroism spectroscopy (Fig. 4B-D). Near-UV CD spectra from 240 to $320 \mathrm{~nm}$ for both the NF-L 68 and SK +70 RNAs were similar (Fig. $4 B, C)$, with $\lambda_{\max }$ at $275 \mathrm{~nm}$ of 6 mdegrees (molar ellipticity). When aldolase A was added at 10-fold molar excess, however, only the spectra for the NF-L 68 RNA was affected (Fig. $4 B$ ), which indicated a possible change in RNA structure after binding. Far-UV CD was used to show that aldolases $\mathrm{C}$ and $\mathrm{A}$ were stabilized by interaction with NF-L 68 RNA (Fig. 4D). $\mathrm{CD}$ intensity was monitored as a function of temperature at $222 \mathrm{~nm}$, a wavelength at which a spectral minimum exists for the $\alpha / \beta$-barrel-fold of aldolase (Morris and Tolan, 1993). The thermal stability of aldolase $A$ was greater than that of aldolase $\mathrm{C}$ with a $T_{\mathrm{m}}$ of 66 and $45^{\circ} \mathrm{C}$, respectively. The addition of NF-L 68 RNA to aldolase $\mathrm{C}$ increased the thermal stability by $13^{\circ} \mathrm{C}$, and the addition of this RNA to aldolase $\mathrm{A}$ increased its stability by $2^{\circ} \mathrm{C}$. Data for both near-UV and far-UV CD support the formation of a complex between neuronal aldolases $\mathrm{A}$ and $\mathrm{C}$ and neurofilament mRNA.

\section{Mapping of aldolase isozyme binding in the $680 \mathrm{nt}$ mouse NF-L stability determinant region}

The minimal sequence in the neurofilament mRNA required for binding of aldolases $\mathrm{A}$ and $\mathrm{C}$ was investigated by deletion analysis (Fig. 5). A 680 nt sequence of capped radiolabeled NF-L mRNA, including the complete 3 '-UTR plus 250 nt of C-terminal coding region produced a mobility shift when incubated with aldolases $\mathrm{A}$ or C but not with aldolase B. Progressive deletion of $3^{\prime}$-UTR sequence did not decrease the binding affinity of aldolase $\mathrm{A}$ or $\mathrm{C}$ until $105 \mathrm{nt}$ of $3^{\prime}$-UTR sequence was deleted. Binding of aldolase A or C was severely impaired after 320 nt was deleted with only 45 nt remaining. In contrast, both aldolases exhibited a shared focal site for binding. This focal point appeared to be the $68 \mathrm{nt}$ element that includes $23 \mathrm{nt}$ of distal coding region plus $45 \mathrm{nt}$ of $3^{\prime}$-UTR and encompasses the translation termination site. In fact, binding of aldolase A to the $45 \mathrm{nt}$ element was barely detectable but could be visualized if the transcript contained some 23 nt upstream of the stop codon. The findings are consistent with a previous observation (Cañete-Soler et al., 1998a) that the formation of a $3^{\prime}$-UTR neurofilament complex in brain extract was accentuated in the presence of distal coding region sequence. To ascer-

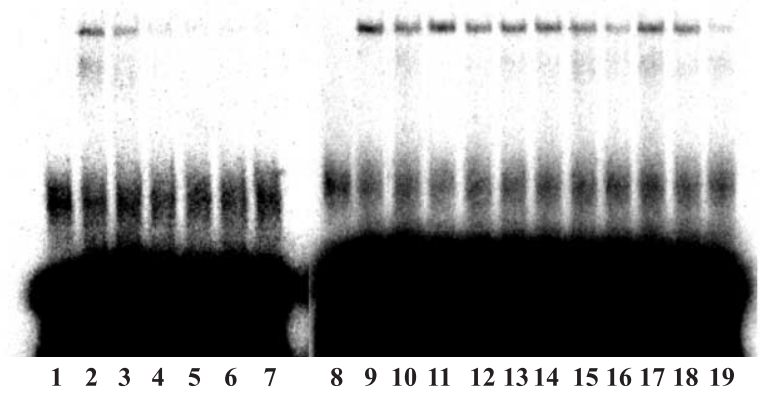

C

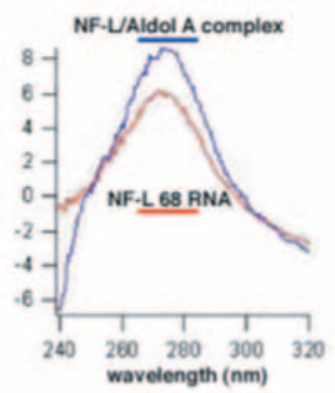

$\mathbf{D}$

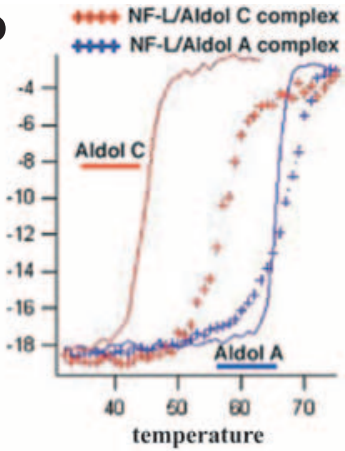

Figure 4. Specificity of formation of aldolase-neurofilament RNA complexes by electrophoretic mobility shift assays and circular dichroism spectroscopy. A, Electrophoretic mobility shift assay after incubation of uncapped radiolabeled NF-L68 with 240-320 nm for RNAs alone, nonspecific SK+70 RNA (B) or with specific NF-L 68 RNA (C), or with aldolase A (Aldol A). D, Far-UV CD spectra of aldolases A (Aldol A) and C (Aldol C) alone or in complex with NF-L 68 RNA. The CD unction of temperature at $222 \mathrm{~nm}$.

tain that the binding of aldolase to the neurofilament transcript is species independent, we tested the ability of the isozymes to bind human NF-L 3'-UTR (Fig. 6). Aldolases A and C interacted with the human sequence (Fig. 6, lanes 2-4) as well as with the $45 \mathrm{nt}$ of proximal 3 '-UTR, harboring few base differences between the human and mouse neurofilaments (Fig. 6, lanes 9-16). The data are consistent with the notion that binding of aldolase to NF-L mRNA is species independent.

\section{Aldolases $A$ and $C$ interact with NF-L mRNA in vivo}

The interaction between the neuronal aldolases and the light neurofilament mRNA occurs in vivo. It was assessed by immunoprecipitation of HA-tagged aldolase A or aldolase C expressed in Neuro-2a cells transfected with a transcribable full-length NF-L cDNA. Neuro-2a cells express very low levels of light NF-L but express the heavy NF-H subunit at levels that are detectable by ribonuclease protection assay. Aldolase expression is also low. Cells were cotransfected with both constructs and immunoprecipitated using a monoclonal HA antibody. Immunoprecipitation efficiency was confirmed by Western blot analysis (Fig. 7A). The nucleic acid was extracted from the immunocomplexes, and RT-PCR was performed using specific primers from the HA vector and neurofilament transgene sequence. The neurofilament transgene primers were selected from sequences $45 \mathrm{nt}$ apart. Primers for the endogenous NF-H, which gives a 617 PCR product, were used as a control for the integrity of RNA in all samples as well as to test for specificity of the mRNA-protein interaction. To better assess the extent of product amplification, the PCRs 


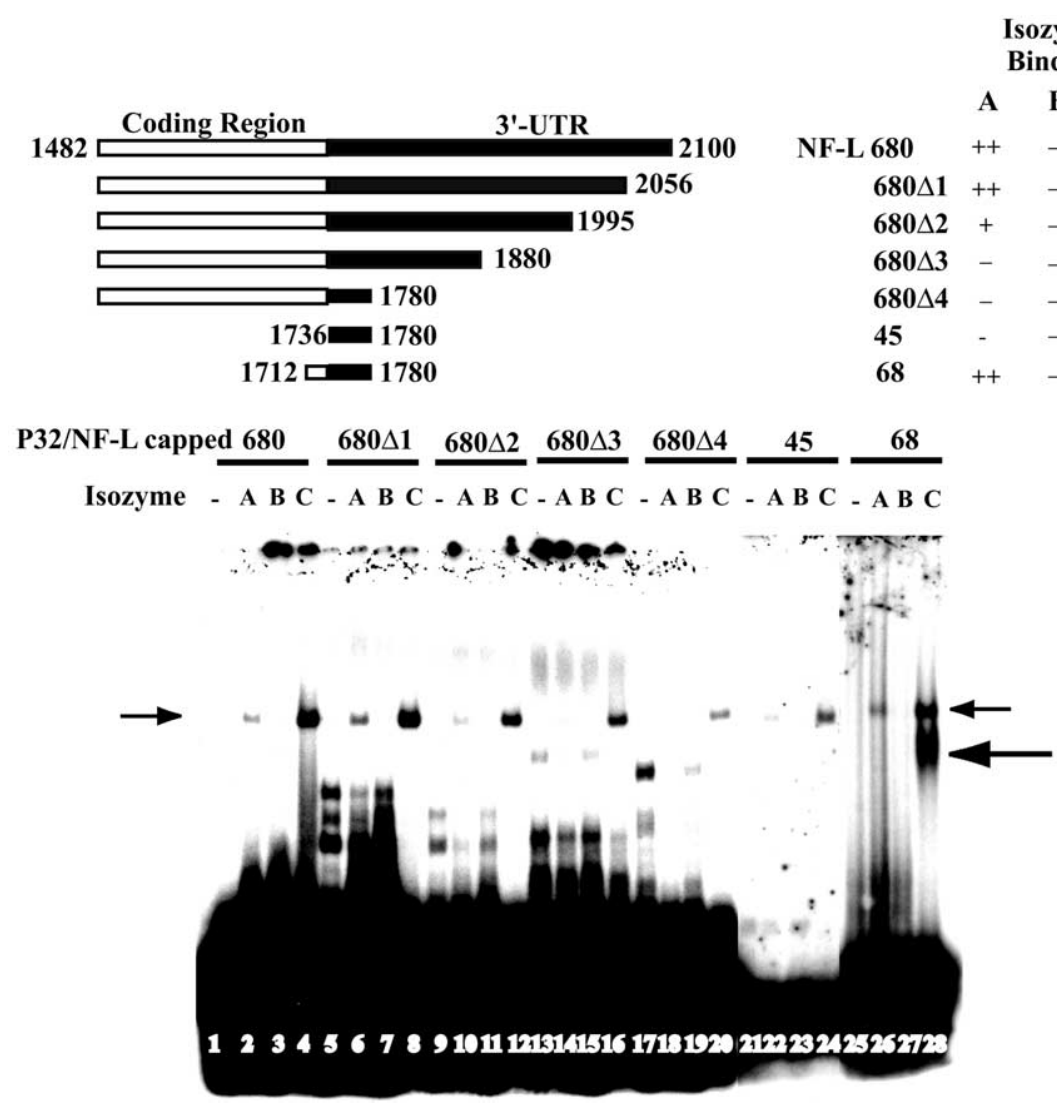

Figure 5. Mapping of protein-binding in the $680 \mathrm{nt}$ mouse neurofilament light stability determinant region. The $680 \mathrm{nt}$ encompasses the full $3^{\prime}$-UTR plus $250 \mathrm{nt}$ of distal coding region of the neurofilament light subunit sequence. Binding reactions were conducted as described in Figure 1. Electrophoretic mobility shift assays of radiolabeled $0.68 \mathrm{~kb}$ RNA sequence (lane 1) or shorter variants depicted in the top panel (lanes 5, 9, 13, 17, 21, 25) were conducted to test for their ability to form band-shifted complexes with $150 \mathrm{ng}$ of purified aldolase $A$ (lanes $2,6,10,14,18,22,26$ ), aldolase $B$ (lanes $3,7,11,15,19,23,27$ ), or aldolase C (lanes 4, 8, 12, 16, 20, 24, 28). Arrows denote the position of the band-shifted complexes.

were supplemented with $0.1 \mu \mathrm{M}$ end-labeled sense primer, and aliquots were taken after 12 and 22 cycles. RNA from immunocomplexes in cells coexpressing HA aldolases A or C plus NF-L generated the expected PCR products corresponding to NF-L RNA transgene (Fig. 7B). The RNA was absent in the control immunoprecipitates from cells expressing the HA vector alone. The absence of PCR product in total lysate for cotransfections with aldolase A (Fig. 7B, lane 5) reflects a lower-transfection efficiency, consistent with one-third less product in the immunoprecipitate (lane 2). RNA from control cells expressing the HA vector alone or coexpressing the HA aldolases plus NF-L (Fig. 7C) generated the expected PCR product for the heavy neurofilament. Note that the intensity of the band is identical in all lysates, indicating that the NF-H has been amplified from endogenous mRNA, equally present in all samples. The band is also present in the immunoprecipitates. This is very likely because of a combination of some nonspecific immunoprecipitation plus carried over lysate that gets artifactually amplified with increasing cycles of PCR. We believe that this is the case, because the band is absent after 11 cycles but is present in all three immunoprecipitations (including control) at 22 cycles. Note that the intensity of the band does not change. The absence of spurious PCR amplification was assessed by using primers for a v-erb B sequence (Fig. 7D). The findings confirmed that the interaction between neurofilament mRNA and aldolases A and $\mathrm{C}$ occurs in vivo, and the interaction is specific for the NF-L mRNA.
Ectopic expression of aldolase increases the degradation rate of the NF-L mRNA To confirm the in vivo significance of aldolase binding to the neurofilament (NF-L) mRNA, Neuro-2a cells were transfected with HA aldolase $\mathrm{C}$ or cotransfected with a tetracycline-inducible NF-L and HA aldolase C. Transfections included tTA and the luciferase reporter to account for transfection efficiency (Fig. 8). mRNA rates of degradation were assessed by ribonuclease protection assay. Parallel experiments were performed to compare the decay of endogenous neurofilaments ( $\mathrm{L}, \mathrm{M}$, and $\mathrm{H}$ ) with that of the light (NF-L) transgene. We used mouse $\beta$-actin as a loading control. Cells transfected with HA aldolase alone revealed detectable but very low levels of endogenous NF-L as well as medium-sized NF (NF-M) and NF-H. However, whereas the NF-L mRNA degraded with time, the levels of NF-M and NF-H were unchanged (Fig. 8, lanes 1-3 and 7-9). Cells cotransfected with aldolase $\mathrm{C}$ and NF-L exhibited high levels of NF-L after induction (Fig. 8, lane 4) but declined quickly after the addition of $0.5 \mu \mathrm{g} / \mathrm{ml}$ doxycycline to deactivate transcription (Fig. 8, lanes 5, 6), indicating that aldolase $\mathrm{C}$ increased the decay rates of the neurofilament transgene. In contrast, the presence of aldolase did not affect the half-life of either endogenous $\mathrm{M}$ or $\mathrm{H}$ (Fig. 8, compare lanes 4-6 with lanes 10-12). The findings support a preferential binding and activity of aldolase on the NF-L mRNA.

To assess the effect of expression of aldolases A and C on the decay of NF-L mRNA in a heterologous system, COS cells were transfected with inducible NF-L or variant mutants lacking sequence for binding of aldolases (Fig. 9). Rates of NF-L mRNA degradation were evaluated as above. Cotransfection of NF-L wt and aldolases A and C (Fig. 9A, lanes 1-4) exhibited NF-L mRNA degradation rates similar to those reported previously (Cañete-Soler et al., 1998b). Cells cotransfected with mutant NF-L lacking $250 \mathrm{nt}$ of distal coding region (Fig. 9A, lanes 5-8) or with deleted 3'-UTR (Fig. 9A, lanes 9-12) showed decreased rates of degradation. The lower signal shown by $\beta$-actin reflects a greater susceptibility of COS cell endogenous $\beta$-actin to RNase treatment in protection assays because of sequence differences. The findings are consistent with a major role of aldolase in modulating the half-life of the light neurofilament in vivo, because deletion of sequences necessary for binding of aldolase stabilizes the transcript. Moreover, they confirm a correlation between in vitro binding to NF-L and a functional effect.

\section{Coexpression of aldolases and the light neurofilament in nonneuronal cells excludes the endogenous $\mathrm{PABP}$ from the complex}

To address potential mechanisms underlying the regulatory effect of aldolase in NF-L mRNA decay, we tested whether aldolases interacted with the PABP within the NF-RNA protein complex. To this end, COS cells were cotransfected with NF-L and HAtagged aldolases (Fig. 10). Ribonucleoprotein (RNP) complexes 


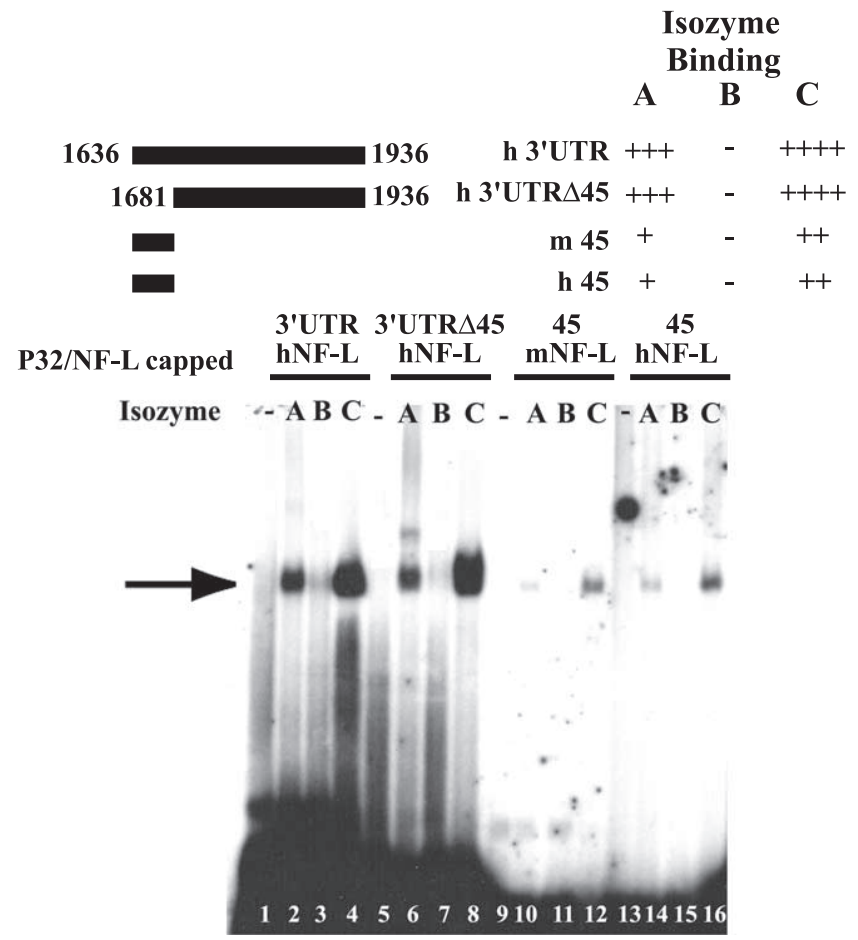

Figure 6. Aldolase-isozyme binding to the $3^{\prime}-U T R$ of the human NF-L (hNF-L) (mRNA). Electrophoretic mobility shift assays of radiolabeled human NF-L $3^{\prime}$-UTR (lanes $1-4$ ) or a variant lacking 45 nt of proximal $3^{\prime}$-UTR (lanes 5-8) or a 45 nt from mouse (lanes 9 -12) or human proximal $3^{\prime}$-UTR (lanes 13-16) depicted in the top panel were conducted to test for their ability to form band-shifted complexes with $150 \mathrm{ng}$ of purified aldolase $\mathrm{A}$ (lanes 2, 6, 10,14), aldolase $B$ (lanes 3, 7, 11, 15), or aldolase C (lanes 4, 8, 12, 16). Arrows denote the position of the band-shifted complexes. mNF-L, Mouse NF-L.

were immunoprecipitated with monoclonal PABP or HA antibodies and immunoblotted with polyclonal PABP or aldolase $\mathrm{C}$ antibodies. Ribonucleoprotein complexes enriched in PABP by immunoprecipitation revealed the presence of the protein in the RNP lysate and immunopellet, and aldolase was found only in the lysate (Fig. 10A). Conversely, when the ribonucleoprotein complexes were immunoprecipitated with $\mathrm{HA}$ antibodies, PABP was found only in the lysate but not in the immunopellet (Fig. $10 \mathrm{~B}$ ). The findings indicate a competitive interaction between aldolase and PABP within the NF-mRNA protein complex and suggest that the modulation of neurofilament stabilization is effected, at least by a competing interaction between aldolases and PABP.

\section{Aldolases A and C exhibit a cap-like-associated ribonucleolytic activity in vitro}

The enhancement of aldolase C binding to a capped NF-L 68 transcript was striking and led us to ask whether the aldolases might have a cap-associated nucleolytic activity. To determine whether this was the case, we incubated a cap-labeled NF-L 68 with $100 \mathrm{~nm}$ purified aldolase $\mathrm{C}$ at $37^{\circ} \mathrm{C}$ for $60 \mathrm{~min}$. Aliquots were taken at varying times and electrophoresed (Fig. $11 \mathrm{~B}$ ). Aldolase $\mathrm{C}$ was able to generate intermediates that retained radioactivity at their $5^{\prime}$-ends. In contrast, when aldolase was incubated with uncapped internally labeled NF-68, no degradation occurred (data not shown). We then sought to restore the cap-like-associated activity by complementation with a factor(s) present in brain extracts (Fig. 11C). Uncapped end-labeled NF-68 was incubated with aldolase in the absence (Fig. 11C, lane 2) or presence of increasing concentrations of brain extract (Fig. 11C, lanes 3-8). Without brain extract, aldolase $\mathrm{C}$ was unable to degrade un-
A

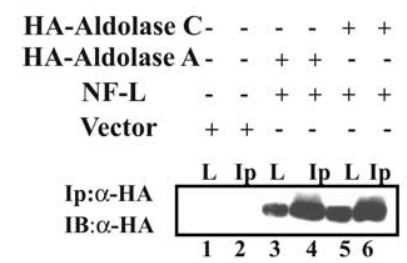

$-\frac{12 \text { cycles }}{\text { Ipp Total Lysate }}$
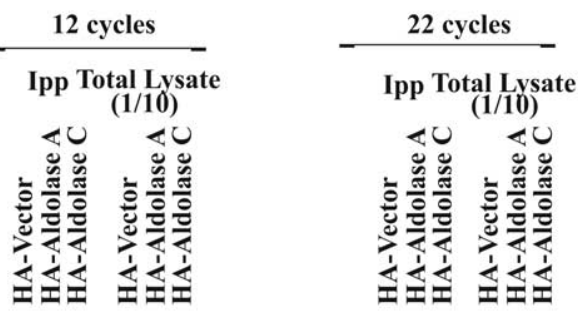

$\begin{array}{rr} & \text { bp } \\ & 500 \\ & 350 \\ 300 \\ 250 \\ 200\end{array}$
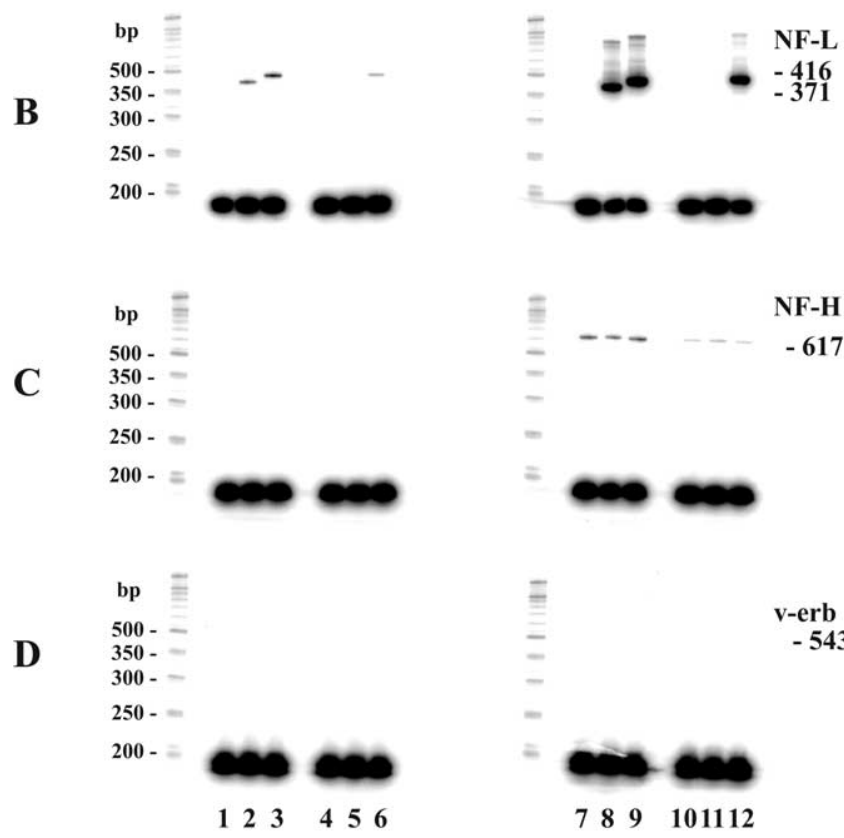

Figure 7. Detection in vivo of direct specific interactions between the NF- $L$ mRNA and aldolases $A$ and $C$ in Neuro-2a cells. $A$, Western blot analyses after HA immunoprecipitation of ribonucleoprotein complexes from cells expressing NF-L and HA-tagged aldolases A and C. IB, Immunoblot; Ip, immunopellet; Ipp, immunoprecipitation; L, lysate. $\boldsymbol{B}-\boldsymbol{D}$, RT-PCR amplification of RNA extracted from immunoprecipitates (lanes 1-3 and 7-9) or one-tenth of total RNP lysate (lanes $4-6$ and 10-12) of cells transfected with vector alone (lanes $1,4,7,10$ ) or cotransfected with NF-L and HA-aldolase A (lanes 2, 5, 8, 11) or HA-aldolase C (lanes 3, 6, 9, 12). Primers for CDNA amplification were from transgene NF-L and vector $(\boldsymbol{B})$, endogenous NF-H ( $(C)$, and $\mathrm{v}$-erb $(\boldsymbol{D})$ sequences. All reactions contained $0.1 \mu \mathrm{m}$ respective end-labeled sense primer. Sample aliquots were withdrawn after 12 and 22 cycles and fractionated in polyacrylamide gels along with radioactive DNA markers.

capped end-labeled transcript (Fig. 11C, compare input lane 2 with lane 3). However, addition of $1.6 \mu \mathrm{g}$ of brain extract was sufficient to initiate a decay process that generated intermediates (Fig. 11C, lanes 4-7). Incubation of the uncapped end-labeled NF-L68 with brain extract in the absence of aldolase C recapitulated the decay process, indicating that an additional capindependent degradation activity is present in brain extract (Fig. $11 D$, lanes $1-4)$. The fragmentation pattern and the size of intermediates suggest that aldolase is an endonuclease, likely the same or very related endonuclease found to be associated with polyribosomes (Lee et al., 1998) and shown to interact with the poly(C) binding protein (Wang and Kiledjian, 2000); however, the possibil- 


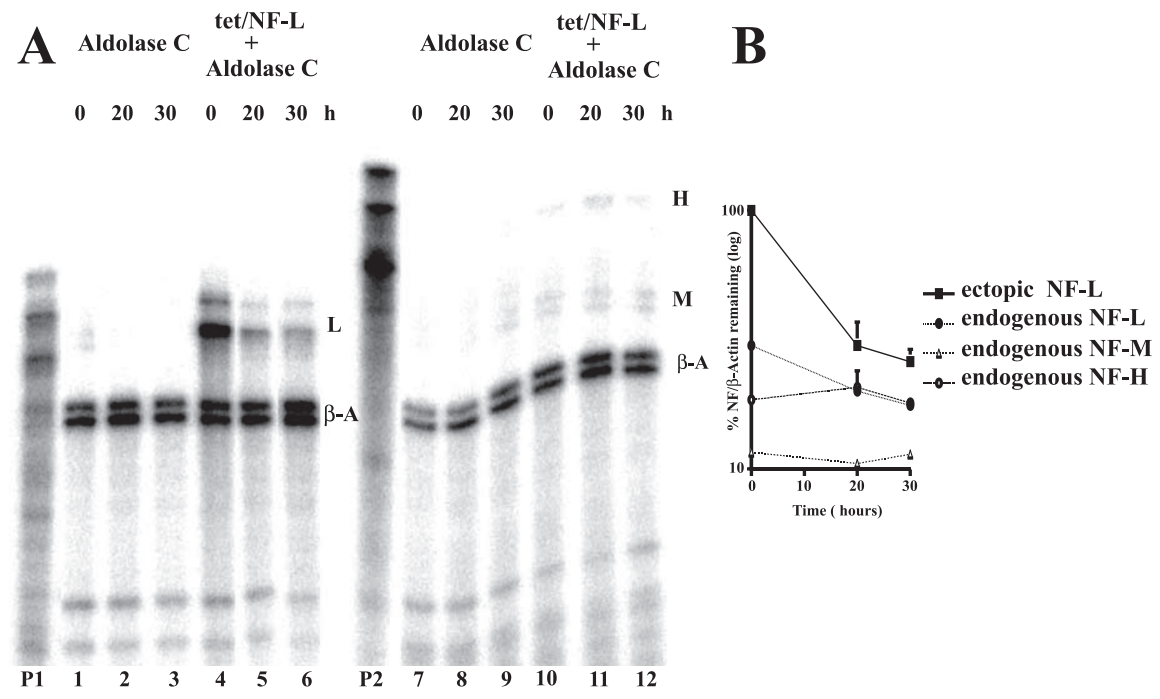

Figure 8. mRNA decay assay of endogenous NF mRNAs or inducible NF- $L$ transgene in the presence of ectopic aldolase in Neuro-2a cells. $\boldsymbol{A}$, Ribonuclease protection assay of NF- and $\beta$-actin $(\beta-A)$ mRNA levels. Target NF- $L$ transgene was activated for $3 \mathrm{~h}$ in the absence of doxycycline and then inactivated by the addition of $0.5 \mu \mathrm{g} / \mathrm{ml}$ ligand (see Materials and Methods). $\boldsymbol{B}$, Quantitation of NF levels normalized to levels of $\beta$-actin mRNA. Data represent the mean of three consecutive independent transfections. H, NF-H; L, NF-L; M, NF-M.
A

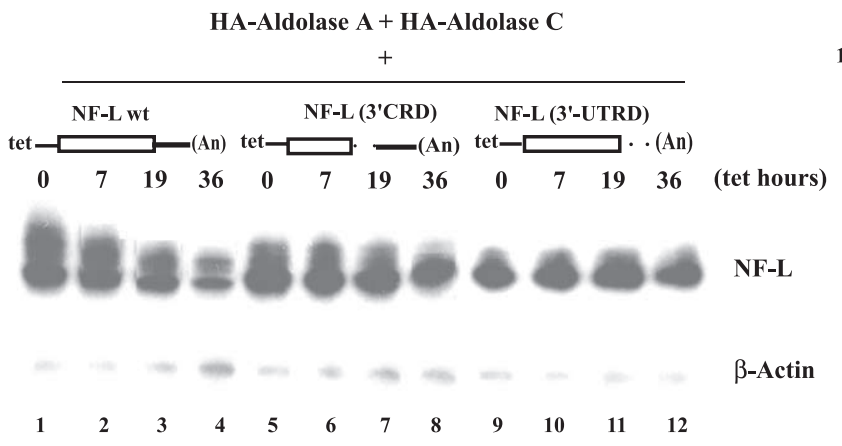

B

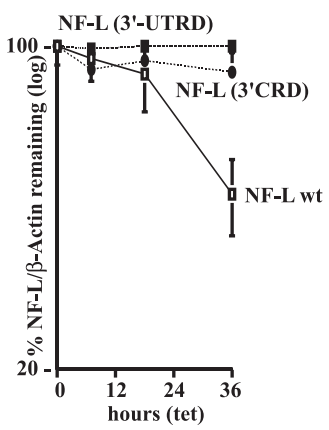

Figure 9. Effect of constitutive ectopic expression of aldolases $A$ and $C$ on the decay of inducible NF-L mRNA and mutant transgenes in $\operatorname{COS}$ cells. $A$, Ribonuclease protection assay of NF-L and $\beta$-actin mRNA levels. Target neurofilament transgenes were activated for $3 \mathrm{~h}$ in the absence of doxycycline and then inactivated by the addition of $0.5 \mu \mathrm{g} / \mathrm{ml}$ ligand (see Materials and Methods). $\boldsymbol{B}$, Quantitation of NF-L mRNA levels normalized to levels of $\beta$-actin mRNA. Data represent the mean of three consecutive independent transfections. An, Poly(A) tail; CRD, coding region deleted; UTRD, UTR deleted.

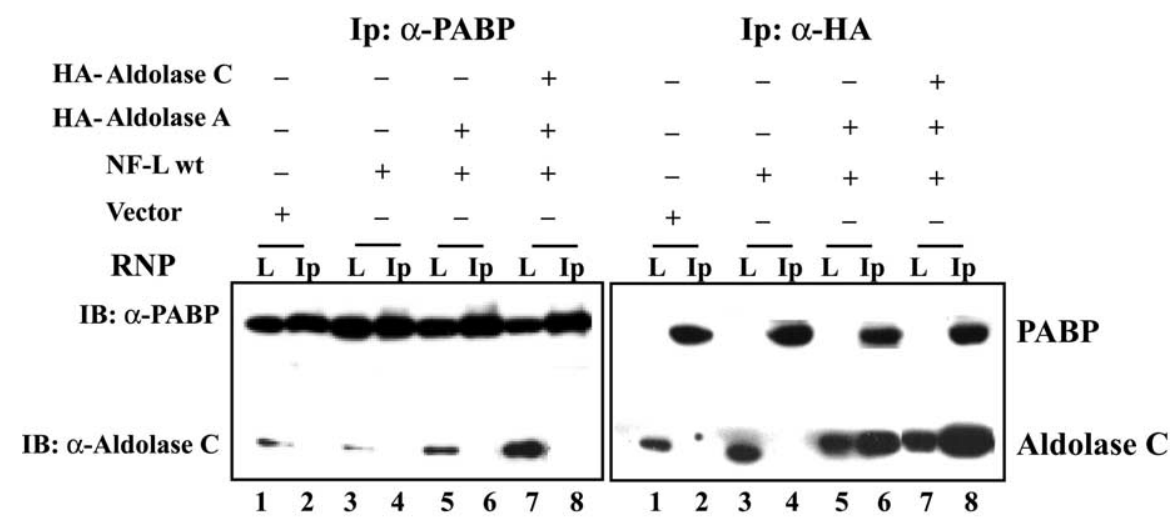

Figure 10. Analysis of NF mRNA protein:protein interactions in cells coexpressing the NF-L and aldolases. $\boldsymbol{A}$, Anti-PABP coimmunoprecipitation assay of RNP complexes from COS cells transfected with indicated plasmids. The immunoprecipitation (Ip) was performed with a monoclonal anti-PABP and immunoblotted (IB) with polyclonals anti-PABP or anti-aldolase C. Specific immunodetection of endogenous PABP (lanes 1-8) and aldolase shows a competing interaction between the two factors. $\boldsymbol{B}$, Anti-HA coimmunoprecipitation assay of RNPs from COS cells coexpressing the same constructs as in $\boldsymbol{A}$. L, Lysate. ity of a distributive exonuclease cannot be discounted (Ross, 1999). A careful examination of the neurofilament sequence revealed the existence of two AUUGA motifs, one of them some $300 \mathrm{nt}$ upstream of the stop codon and the second one at the translation termination site. The findings suggest that aldolase $C$ could be the same endoribonuclease that cleaves $\beta$-globin mRNA at UG sites and could be part of a specialized decay pathway that overlaps the general non-sensemediated decay pathway (Stevens et al., 2002). Moreover, a previous report on hu$\operatorname{man} \beta$-globin mRNAs harboring a nonsense codon has shown that the degradative intermediates bound an anti-cap antibody and were resistant to $5^{\prime}$ to $3^{\prime}$ exonuclease activity (Lim and Maquat, 1992). Together, the findings suggest that the neuronal aldolases are nucleases that cleave the neurofilament transcript at specific UG sites. Their activity might be dependent on a yet unidentified cellular activity that "marks" the transcript at its $5^{\prime}$-end to be recognized by aldolases A and C. Validation of this possible mechanism awaits additional studies.

\section{Discussion}

This report identifies the neuronal aldolases $\mathrm{A}$ and $\mathrm{C}$ as components of an NF-L mRNA complex and describes novel, specific interactions between the glycolytic enzymes and the neuronal transcript. These interactions are not fortuitous in that we show that the enzymes regulate the stability of NF-L mRNA in vivo. We also begin to address the mechanisms whereby aldolases $\mathrm{A}$ and $\mathrm{C}$ partake in regulating NF-L mRNA stability by demonstrating that the enzymes exhibit ribonuclease activity and undergo competitive interactions with the PABP in vivo. Our findings indicate that aldolases $\mathrm{A}$ and $\mathrm{C}$ are instrumental components of a ribonucleoprotein complex that modulates the stability of the NF-L transcript, possibly by activation of their ribonucleolytic activity. It is unclear whether the role of aldolases in mediating high-energy consumption in large neurons may be related to their regulation of NF-L mRNA expression.

Aldolases are glycolytic enzymes catalyzing reactions in the glycolytic, gluconeogenic, and fructose metabolic pathways. Three vertebrate isozymes (A, B, and C) are conserved through evolution (Berardini et al., 1997). They are tetrameric enzymes and do not possess classical RNAbinding motifs (Burd and Dreyfuss, 1994). Aldolase A is expressed predominantly in muscle and brain, aldolase $\mathrm{B}$ is expressed predominantly in liver, and aldolase $\mathrm{C}$ is expressed predominantly in brain (Leb- 
erhz and Rutter, 1969; Ahn et al., 1994). Aldolase $\mathrm{C}$ may also have moonlighting activities in establishing subsets of neurons during cerebellar development (Hawkes et al., 1993; Ahn et al., 1994) or during differentiation of progenitor cells in the subventricular zones of the developing brain (Staugaitis et al., 2001). Like neurofilament transcripts, aldolases $\mathrm{A}$ and $\mathrm{C}$ are expressed early in embryonic development, are upregulated during postnatal life (Kusakabe et al., 1997; Shiokawa et al., 2002), and are also differentially expressed in complementary cell types (Walther et al., 1998). Aldolase binds to the actin cytoskeleton and mediates the association of F-actin with the insulin-responsive glucose transporter GLUT4 (Kusakabe et al., 1997; Wang et al., 1997; Kao et al., 1999; Jewet and Sibley, 2003); however, the association with a neuronal mRNA was only recently uncovered (Cañete-Soler et al., 2003).

The interaction between aldolase and NF-L mRNA is restricted to the two neuronal isozymes. Why the mammalian brain needs two very similar glycolytic enzymes is not understood (Rottmann et al., 1987). The differential pattern of expression of aldolases A and C in brain is reminiscent of the shifting pattern of $\mathrm{Hu}$ expression during neuronal differentiation in mouse (Okano and Darnell, 1997), chicken (Wakamatsu and Weston, 1997), Xenopus (Perron et al., 1999), and zebrafish (Park et al., 2000). It suggests that sets of RNA-binding proteins in varying composition in ribonucleoprotein complexes (Keene and Tenembaum, 2002) may have differing effects on differentiation in subsets of neurons. It has been shown that the neuronal ELAV (embryonic lethal abnormal vision)-like protein (Hel-N1) does not affect the steady-state levels of NF-M mRNA, despite the fact that Hel-N1 binds to the $3^{\prime}$-UTR of NF-M and associates directly with the transcript in transfected cells. However, it was observed that cells overexpressing Hel-N1 had NF-M actively translated, because it migrated with the heavy polysome fraction and suggested that expression of Hel-N1 favored reinitiation of NF-M translation (Antic et al., 1999). Instead, the neuronal aldolases bind the $3^{\prime}$-UTR of the NF-L mRNA, and their binding does modify the steady-state levels of the transcript. These differing effects indicate that the overall coordinated expression of the three neurofilament subunits could be achieved by a concerted regulation that is dependent on the master neurofilament subunit (NF-L). This would not be surprising because the NF-L is indispensable for assembly of NF-H or NF-M subunits (Ching and Liem, 1993; Lee et al., 1993). The increasing evidence in the relationship between mRNA stability and translation in eukaryotic cells (Jacobson and Peltz, 1996; Grosset et al., 2000; Lemn and Ross, 2002) supports the notion that the coordinated expression of neurofilaments could be achieved at different steps of the translation process, possibly with the intervention of other gene products (e.g., non-
B

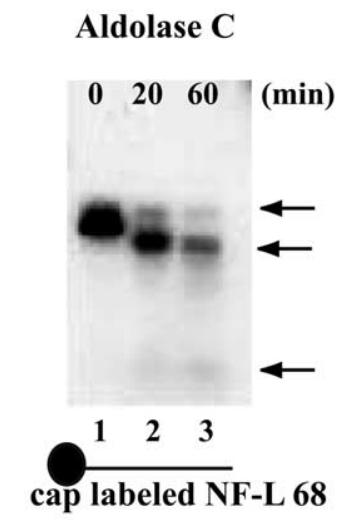

D
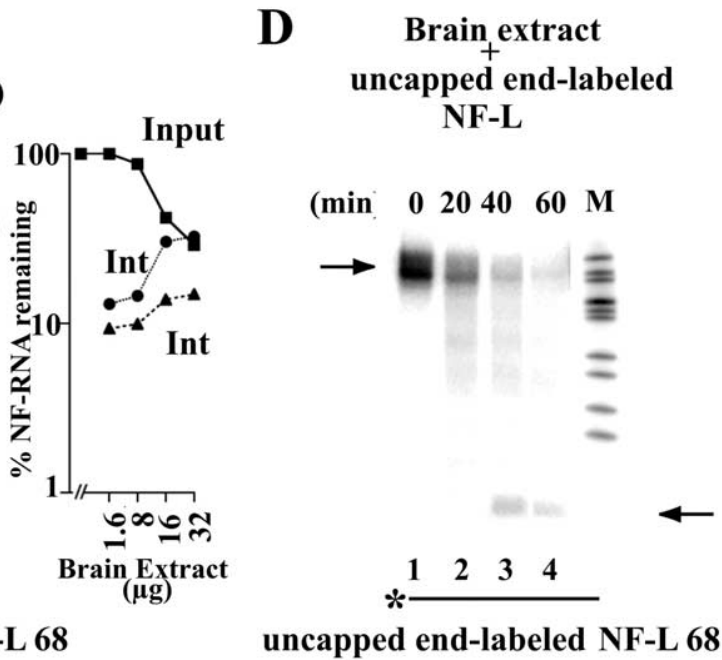

uncapped end-labeled NF-L 68

Figure 11. Ribonucleolytic activity of aldolase. $\boldsymbol{A}$, Diagram of NF- $L$ transcripts used in degradation assays. NF- $L 68$ encompasses $23 \mathrm{nt}$ of distal coding region and $45 \mathrm{nt}$ of proximal $3^{\prime}$-UTR, cap-labeled with vaccinia-guanyltransferase and $\mathrm{P}^{32} \alpha$-GTP (top diagram) or uncapped but end-labeled with $\mathrm{P}^{32}$ from $\gamma$-ATP (bottom diagram). The arrow indicates a potential cleavage site. , Degradation assay after incubation of $100 \mathrm{~nm}$ purified aldolase C with cap-labeled NF-L 68. C, Degradation assay after incubation of uncapped end-labeled NF-68 with $100 \mathrm{~nm}$ aldolase C in the absence (lane 3) or presence of increasing amounts of brain extract (lanes 4 -8). Quantitation of input uncapped NF-68 and intermediates as a function of added brain extract concentration (see Results). $\boldsymbol{D}$, Degradation assay of uncapped end-labeled NF-L 68 by activities present in brain extract.

coding RNAs, RNA-binding proteins) in different sets of RNPs (Antic et al., 1999).

It is also conceivable that differential composition of RNP complexes in subsets of neurons could determine their differential susceptibility to degenerative conditions or vulnerability to adverse mutations. We have shown previously that a mutant NF-L transgene, with a disrupted configuration at the junction of the coding region and 3'-UTR (Cañete-Soler et al., 1999), or overexpression of neurofilament RNA sequences placed in the 3'-UTR of a GFP reporter gene (Nie et al., 2002) has profound neuropathic effects on motor neurons in mice. Here, we show that coexpression of NF-L mRNA and aldolase C leads to an increased rate of degradation of the NF-L transcript. Moreover, the degradation rate is inhibited when aldolases are coexpressed with mutant NF-L that lacks mRNA sequence for binding of aldolase. The findings raise the possibility that disruption of a homeostatic neurofilament NF-L mRNA complex might occur by the following: (1) titrating out a component(s) of the complex if the NF-L mRNA is misexpressed (Xu et al., 1993; Bergeron et al., 1994; Nie et al., 2002), or (2) preventing adequate binding of 
aldolase if the proper contiguity between coding region and $3^{\prime}$ UTR is altered (Lee et al., 1994; Cañete-Soler et al., 1999; Amrani et al., 2004). In either case, alterations in the number of NFs might not be the cause of the disease phenotype but rather the effect of the aberrant positioning or composition of a complex that becomes the target of disruptive interactions among specific and general components of the posttranscriptional machinery.

Aldolases A and C bind with different affinities to the NF-L, and their differential affinity is also manifested in differential ribonuclease activity. This raises the intriguing possibility that cells that coexpress aldolases $\mathrm{A}$ and $\mathrm{C}$ have heterotetramers that bind and act differently than the homotetramers present in cells that express one isozyme or the other. That the NF-L 68 element binds so effectively to aldolase contrasts with the poor binding of NF-L $680 \Delta 4$, despite the fact that NF-L $680 \Delta 4$ contains also the $23 \mathrm{nt}$ upstream of the stop codon. It suggests that there must be a negative element (anti-determinant) upstream in the coding region, which, when removed, allows full binding of aldolase. It is also possible that the function of the $68 \mathrm{nt}$ element in vivo is to approximate sequences in the coding region with those in the $3^{\prime}$-UTR. This structural proximity could be necessary for interaction between the two isozymes and specific activation of their activity in subsets of neurons. A similar strategy has been reported to occur in tissue-specific regulation of alternative splicing (Baraniak et al., 2003). There is also increasing evidence that RNA conformations play an active role in regulating gene expression in a variety of experimental settings (Woodson, 2000; Muh et al., 2002; Tian et al., 2004).

Aldolase activity on the NF-L mRNA appears to be endonucleolytic judging by the appearance of discrete intermediates, although a distributive exonucleolytic activity cannot be dismissed. Aldolases A and C promote fragmentation of a capped but not an uncapped NF-L unless an additional activity is provided in trans by supplementation with brain extracts. The findings are reminiscent of the human $\beta$-globin mRNAs for which degradation was reported to be associated to a $5^{\prime}$-end cap-like structural element (Lim and Maquat, 1992).

Aldolase competes with the PABP in vivo. This is in contrast with the positive interaction exhibited by the $\alpha$-CP proteins (for review, see Waggoner and Liebhaber, 2003) and suggests that aldolases and the $\alpha$-CP proteins could act in concert to regulate expression of other transcripts. Because aldolases accelerate the degradation rate of the NF-L in vivo, we propose that the neuronal isozymes are ribonucleolytic components of a neuronal surveillance complex that ensures the quality and efficiency of neurofilament expression. A defective neurocytoskeletal network, resulting from unproductive aldolase/NF-mRNA interactions could negatively affect the local concentrations of general translation factors or impair recycling of translational components (Decker and Parker, 1995; Mangus et al., 2003; Amrani et al., 2004). This, in turn, might have effects in trans with deleterious consequences for the normal expression of other gene products (Lin et al., 2004; Ge et al., 2005). The latter becomes critical for large neurons with extraordinary high metabolic demands at specific sites (Wu et al., 1997).

In summary, this study provides novel insights in the field of RNA-protein interactions in the nervous system. It shows that proteins believed to have metabolic functions also regulate the expression of a prominent neuron-specific mRNA. Moreover, it underscores the complexities of the gene expression circuitry for regulating neuronal function and dysfunction (Keene, 2003).

\section{References}

Ahn AH, Dziennis S, Hawkes R, Herrup K (1994) The cloning of zebrin II reveals its identity with aldolase C. Development 120:2081-2090.

Amrani N, Ganesan R, Kervestin S, Mangus DA, Ghosh S, Jacobson A (2004) A faux $3^{\prime}$-UTR promotes aberrant termination and triggers non-sensemediated mRNA decay. Nature 432:118-129.

Antic D, Lu N, Keene JD (1999) ELAV tumor antigen, Hel-N1, increases translation of neurofilament M mRNA and induces formation of neurites in human teratocarcinoma cells. Genes Dev 13:449-461.

Baraniak AP, Lasda EL, Wagner EJ, García-Blanco M (2003) A stem structure in fibroblast growth factor receptor 2 transcripts mediates cell typespecific splicing by approximating intronic control elements. Mol Cell Biol 23:9327-9337.

Berardini TZ, Drygas-Williams M, Callard GV, Tolan DR (1997) Identification of neuronal isozyme specific residues by comparison of goldfish aldolase C to other aldolases. Comp Biochem Physiol 117A:471-476.

Bergeron C, Beric-Maskarel K, Muntasser S, Weyer L, Somerville MJ, Percy ME (1994) Neurofilament light and polyadenylated mRNA levels are decreased in amyotrophic lateral sclerosis motor neurons. J Neuropathol Exp Neurol 53:221-230.

Brosius J (2003) Gene duplication and other evolutionary strategies: from the RNA world to the future. J Struct Funct Genomics 3:1-17.

Burd CG, Dreyfuss G (1994) Conserved structures and diversity of functions of RNA-binding proteins. Science 265:615-621.

Cañete-Soler R, Schwartz ML, Hua Y, Schlaepfer WW (1998a) Stability determinants are localized to the $3^{\prime}$ UTR and $3^{\prime}$ coding region of the neurofilament light subunit mRNA using a tetracycline-inducible promoter J Biol Chem 273:12650-12654

Cañete-Soler R, Schwartz ML, Hua Y, Schlaepfer WW (1998b) Characterization of ribonucleoprotein complexes and their binding sites on the neurofilament light subunit mRNA. J Biol Chem 273:12655-12661.

Cañete-Soler R, Silberg DG, Gershon MD, Schlaepfer WW (1999) Mutation in neurofilament transgene implicates RNA processing in the pathogenesis of neurodegenerative disease. J Neurosci 19:1273-1283.

Cañete-Soler R, Wu J, Zhai J, Shamim M, Schlaepfer WW (2001) p190RhoGEF binds to a destabilizing element in the 3'UTR of NF-L mRNA and alters the stability of the transcript. J Biol Chem 276:32046-32050.

Cañete-Soler R, Shamim M, Zhai J, Lin H, Reddy KS (2003) The glycolytic enzymes aldolases $\mathrm{A}$ and $\mathrm{C}$ moonlight by binding the instability determinant of the NF-L mRNA. Paper presented at The RNA Society of North Carolina Symposium on RNA Biology V: RNA, Tool and Target, Research Triangle Park, NC, October.

Chen CY, You Y, Shyu AB (1992) Two cellular proteins bind specifically to a purine-rich sequence necessary for the destabilization function of a c-fos protein-coding region determinant of mRNA instability. Mol Cell Biol 12:5748-5757.

Ching GY, Liem RK (1993) Assembly of type IV neuronal intermediate filaments in nonneuronal cells in the absence of preexisting cytoplasmic intermediate filaments. J Cell Biol 122:1323-1335.

Decker CJ, Parker R (1995) Diversity of cytoplasmic functions for the 3' untranslated region of eukaryotic transcripts. Curr Opin Cell Biol 7:386-392.

Ford LP, Watson J, Keene JD, Wilusz J (1999) ELAV proteins stabilize deadenylated intermediates in a novel in vitro mRNA deadenylation/degradation system. Genes Dev 13:188-201.

Ge WW, Wen W, Strong W, Leystra-Lantz C, Strong MJ (2005) Mutant copper-zinc superoxide dismutase binds to and destabilizes human low molecular weight neurofilament mRNA. J Biol Chem 280:118-124.

Grosset C, Chen CY, Xu N, Sonenberg N, Jacquemin-Sablon H, Shyu AB (2000) A mechanism for translationally coupled mRNA turnover: interaction between the poly (A) tail and a c-fos RNA coding determinant via a protein complex. Cell 103:29-40.

Hawkes R, Blyth S, Chockkan V, Tano D, Ji Z, Mascher C (1993) Structural and molecular compartmentation in the cerebellum. Can J Neurol Sci 20 [Suppl 3]:S29-S35.

Hentze MW (1994) Enzymes as RNA-binding proteins: a role for (di)nucleotide-binding domains? Trends Biochem Sci 19:101-103.

Hentze MW, Kuhn LC (1996) Molecular control of vertebrate iron metabolism: mRNA-based regulatory circuits operated by iron, nitric oxide, and oxidative stress. Proc Natl Acad Sci USA 93:8175-8182.

Holcik M, Liebhaber SA (1997) Analysis of mRNP complexes assembled in 
vitro. In: mRNA formation and function (Richter JD, ed), pp 196-208. New York: Academic.

Jacobson A, Peltz SW (1996) Interrelationships of the pathways of mRNA decay and translation in eukaryotic cells. Annu Rev Biochem 65:693-739.

Jeffery C (2003) Moonlighting proteins: old proteins learning new tricks. Trends Genet 19:415-417.

Jewet TJ, Sibley D (2003) Aldolase forms a bridge between cell surface adhesions and the actin cytoskeleton in apicomplexan parasites. Mol Cell 11:885-894.

Kao AW, Noda Y, Johnson JH, Pessin JE, Saltiel AR (1999) Aldolase mediates the association of F-actin with the insulin-responsive glucose transporter GLUT4. J Biol Chem 274:17742-17747.

Keene JD (2003) Post-transcriptional generation of macromolecular complexes. Mol Cell 12:1347-1349.

Keene JD, Tenembaum SA (2002) Eukaryotic mRNPs may represent posttranscriptional operons. Mol Cell 9:1161-1167.

Kennedy MC, Mende-Mueller L, Blondin GA, Beinert H (1992) Purification and characterization of cytosolic aconitase from beef liver and its relationship to the iron-responsive element binding protein. Proc Natl Acad Sci USA 89:11730-11734.

Kusakabe T, Motoki K, Hori K (1997) Mode of interactions of human aldolase isozymes with cytoskeletons. Arch Biochem Biophys 344:184-193.

Leberhz HG, Rutter WJ (1969) Distribution of fructose diphosphate aldolase variants in biological systems. Biochemistry 8:109-121.

Lee CH, Leeds P, Ross J (1998) Purification and characterization of a polysome-associated endoribonuclease that degrades c-myc mRNA in vitro. J Biol Chem 273:25261-25271.

Lee MK, Xu Z, Wong PC, Cleveland DW (1993) Neurofilaments are obligate heteropolymers in vivo. J Cell Biol 122:1337-1350.

Lee MK, Marszalek JR, Cleveland DW (1994) A mutant neurofilament subunit causes massive, selective motor neuron death: implications for the pathogenesis of human motor neuron disease. Neuron 13:975-988.

Lemn I, Ross J (2002) Regulation of c-myc mRNA decay by translational pausing in a coding region instability determinant. Mol Cell Biol 22:3959-3969.

Lim S-K, Maquat LE (1992) Human $\beta$-globin mRNAs that harbor a nonsense codon are degraded in murine erythroid tissues to intermediates lacking regions of exon I or exons I and II that have a cap-like structure at the 5 'termini. EMBO J 11:3271-3278.

Lin H, Zhai J, Cañete-Soler R, Schlaepfer WW (2004) 3' untranslated region in a light neurofilament (NF-L) mRNA triggers aggregation of NF-L and mutant superoxide dismutase 1 proteins in neuronal cells. J Neurosci 24:2716-2726.

Mangus DA, Evans MC, Jacobson A (2003) Poly(A)-binding proteins: multifunctional scaffolds for the post-transcriptional control of gene expression. Genome Biol 4:223.

Morris AJ, Tolan DR (1993) Site-directed mutagenesis identifies aspartate 33 as a previously unidentified critical residue in the catalytic mechanism of rabbit aldolase A. J Biol Chem 268:1095-1100.

Muh SJ, Hovhannisyan RH, Carstens R (2002) A non-sequence-specific double-stranded RNA structural element regulates splicing of two mutually exclusive exons of fibroblast growth factor receptor 2 (FGFR2). J Biol Chem 277:50143-50154.

Nagy E, Henics T, Eckert M, Misetta A, Lightowlers RN, Kellermayer M (2000) Identification of the NAD+-binding fold of glyceraldehyde 3-phosphate dehydrogenase as a novel RNA-binding domain. Biochem Biophys Res Commun 275:253-260.

Nie Z, Wu J, Zhai J, Lin H, Ge W, Schlaepfer WW, Cañete-Soler R (2002) Untranslated element in neurofilament mRNA has neuropathic effect on motor neurons of transgenic mice. J Neurosci 22:7662-7670.

Okano HJ, Darnell RB (1997) A hierarchy of Hu RNA binding proteins in developing and adult neurons. J Neurosci 17:3024-3037.

Park HC, Hong KS, Kim HS, Yoon EJ, Kim CH, Miki N, Huh TL (2000) Structural comparison of zebrafish Elav/Hu and their differential expressions during neurogenesis. Neurosci Lett 279:81-84.

Penhoet EE, Rutter WJ (1971) Catalytic and immunochemical properties of homomeric and heteromeric combinations of aldolase subunits. J Biol Chem 246:318-323.

Perron M, Furrer MP, Wegnez M, Theodore L (1999) Xenopus elav-like genes are differentially expressed during neurogenesis. Mech Dev 84:139-142.
Pezza JA, Choi KH, Berardini TZ, Beernink PT, Allen KN, Tolan DR (2003) Spatial clustering of isozyme-specific residues reveals unlikely determinants of isozyme specificity in fructose-1,6-bisphosphate aldolase. J Biol Chem 278:17307-17313.

Pioli PA, Hamilton BJ, Connolly JE, Brewer G, Rigby WF (2002) Lactate dehydrogenase is an AU-rich element-binding protein that directly interacts with AUF1. J Biol Chem 277:35738-35745.

Ross J (1999) Assays for analyzing exonucleases in vitro. Methods 17:52-59.

Rottmann WH, Deselms KR, Niclas J, Camerato T, Holman PS, Green CJ, Tolan DR (1987) The complete amino acid sequence of the human aldolase $\mathrm{C}$ isozyme derived from genomic clones. Biochimie 69:137-145.

Shiokawa K, Kajita E, Hara H, Yatsuki H, Hori K (2002) A developmental biological study of aldolase gene expression in Xenopus laevis. Cell Res 12:85-96.

Sioud M, Jespersen L (1996) Enhancement of hammerhead ribozyme catalysis by glyceraldehyde-3-phosphate dehydrogenase. J Mol Biol 257:775-789.

Speicher DW, Reim D (1997) N-terminal sequence analysis. In: Current protocols in protein science (Coligan J, ed), pp 11.10.1-11.10.38. New York: Wiley.

Speicher KD, Kolbas O, Harper S, Speicher DW (2000) Systematic analysis of peptide recoveries from in-gel digestions for femtomole protein identifications in proteome studies. J Biomol Tech 11:74-86.

Staugaitis SM, Zerlin M, Hawkes R, Levine JM, Goldman JE (2001) Aldolase $\mathrm{C} /$ zebrin II expression in the neonatal rat forebrain reveals cellular heterogeneity within the subventricular zone and early astrocyte differentiation. J Neurosci 21:6195-6205.

Stevens A, Wang Y, Bremer K, Zhang J, Hoepfner R, Antoniou M, Schoenberg DR, Maquat LE (2002) $\beta$-Globin mRNA decay in erythroid cells: UG site-preferred endonucleolytic cleavage that is augmented by a premature termination codon. Proc Natl Acad Sci USA 99:12741-12746.

Tian B, Bevilacqua PC, Diegelman-Parente A, Mathews MB (2004) The double-stranded RNA-binding motif: interference and much more. Nat Rev Mol Cell Biol 5:1013-1023.

Xu Z, Cork LC, Griffin JW, Cleveland DW (1993) Increased expression of neurofilament subunit NF-L produces morphological alterations that resemble the pathology of human motor neuron disease. Cell 73:23-33.

Waggoner SA, Liebhaber SA (2003) Regulation of $\alpha$-globin mRNA stability. Exp Biol Med 228:387-395.

Wakamatsu Y, Weston JA (1997) Sequential expression and role of Hu RNAbinding proteins during neurogenesis. Development 124:3449-3460.

Walther EU, Dichgans M, Maricich SM, Romito RR, Yang F, Dziennis S, Zackson S, Hawkes R, Herrup K (1998) Genomic sequences of aldolase $\mathrm{C}$ (Zebrin II) direct lacZ expression exclusively in non-neuronal cells of transgenic mice. Proc Natl Acad Sci USA 95:2615-2620.

Wang J, Tolan DR, Pagliaro L (1997) Metabolic compartmentation in living cells: structural association of aldolase. Exp Cell Res 237:445-451.

Wang Z, Kiledjian M (2000) Identification of an erythroid-enriched endoribonucleolytic activity involved in specific mRNA cleavage. EMBO J 19:295-305.

Wilkinson M, Shyu AB (2001) Multifunctional regulatory proteins that control gene expression in both the nucleus and the cytoplasm. BioEssays 23:775-787.

Wilusz J (1997) Rapid identification and cloning of sequence-specific RNAbinding proteins. In: mRNA formation and function (Richter JD, ed), pp 99-109. New York: Academic.

Woodson SA (2000) Recent insights on RNA folding mechanisms from catalytic RNA. Cell Mol Life Sci 57:796-808.

Wu K, Aoki C, Elste A, Rogalski-Wilk AA, Siekevitz P (1997) The synthesis of ATP by glycolytic enzymes in the postsynaptic density and the effect of endogenously generated nitric oxide. Proc Natl Acad Sci USA 94:13273-13278.

Zheng L, Roeder RG, Luo Y (2003) S phase activation of the histone H2B promoter by OCA-S, a coactivator complex that contains GAPDH as a key component. Cell 114:255-266.

Zhu Q, Lindenbaum M, Levavasseur F, Jacomy H, Julien J-P (1998) Disruption of the NF-H gene increases axonal microtubule content and velocity of neurofilament transport: relief of axonopathy resulting from the toxin iminodipropionitrile. J Cell Biol 143:183-193. 